\title{
DEVELOP A CLEANING AND GRADING UNIT FOR BROAD BEANS CROP
}

\author{
S. H. Dosoky*
}

ABSTRACT

The present study aims to modify and develop a small, simple, and cheep machine for cleaning and grading Egyptian crop seeds by using both mechanical and aerodynamic methods, suitable for the small village. The developed machine was constructed locally from available material which purchased from domestic market and fabricated to ensure low initial cost and availability of spare parts and ease cleaning and repair. The parameters involved in grading machine and analysis the behavior of particles and forces acting during grading process, to achieve the optimum conditions for cleaning, grading and conveying operations. To evaluate the performance of the modified cleaning and grading machine, a series of experiments were carried out to study some parameters, such as the effect of screen oscillation speed inclination, Broad beans (Giza 461); grading operations. The main results obtained from the experiments were summarized in the following main points:-

Te average mas of 1000 kernels 7579, Length $14.7 \mathrm{~mm}$, width $11 \mathrm{~mm}$, thickness $6 \mathrm{~mm}$, specific density $1.28 \mathrm{~g} / \mathrm{cm} 3$, projected area $2.15 \mathrm{~cm} 2$, terminal velocity 12.4 drag coefficient 0.396, Reynolds number 1170, and spherically 0.66 at M.C 14-18\%. Separation efficiency was $98 \%$ at screen oscillation 2/5 rpm, Zero deg. feed rate $250 \mathrm{~kg} / \mathrm{h}$. Grain recovery was $99 \%$, grain loss was $0.70 \%$, and grain clean lines was $98 \%$ at the same conditions.

\section{INTRODUCTION}

The seed physical properties, such as dimensional (size) and specific gravity are used in separation between the desirable and undesirable seeds, to give the most efficient operation. Mohsenin (1984) mentioned that the physical properties of materials such as shape, size and surface or projected area are important in many problems associated with design or development of specific machine.

\footnotetext{
"Assist. Prof. of Agric. Eng., Faculty of Agric. Eng. Cairo, Al-Azhar Univ.
} 
Analysis of the behavior of the product in separation of grain is among the important design parameters in conveying of solid materials by air on the assumption of the shape of the materials accurate estimation of frontal area and the related. Diameters are essential for the determination of terminal velocity, drag coefficient, and Reynolds number. Awady and El Sayed (1994) stated that when air stream is used for separation of a product from its associated foreign materials, knowledge of terminal velocity of all the particles is involved for these reasons. Terminal velocity has been used as an important aerodynamic characteristic of material in such applications as pneumatic conveying and separation from foreign materials. Khairy and Nakib (1989) found that the differences between suspension or terminal velocity of hulled mixture components of sunflower seed were small and equal to $0.3,0.8$ and $1 \mathrm{~m} / \mathrm{s}$ for hulls, broken kemels, unshelled kernels resp. this is due to the slight differences of properties of the mixture components. Dosoky (2011), studied some physical, mechanical and aerodynamic properties as seed dimensions (length, width and thickness) mass, density and projected area, terminal velocity, drag coefficient and Reynolds number for Soybeans seed separation. These factors must be considered to increase separation accuracy by selection of air velocity relative to grain.

The objectives of this study are to evaluate some engineering operational factors, developing a seed cleaning and grading unit as the following: slopes, speeds and stroke length of the sieving unit, rates of feeding, conveying unit, speeds and clearances, air velocity suited with terminal velocity of grain, and seed physical aerodynamically properties.

The above mentioned considerations and properties may affect machine capacity, grading and cleaning efficiency, grain, recovery, grain losses, power and energy consumption. The machine is tested with the broad bens seeds.

\section{MATERIALS AND METHODS}

Through the present study some physical, aerodynamic and mechanical properties of broad beans, Giza 461 was investigated. The mentioned properties may be utilized as engineering parameters for design and 
development of a cleaning and grading machine. The engineering and operational factors affecting the design of a seed cleaning and grading were studied on the prototype unit was conducted at Agri. Eng. Collect, Al- Azhar Univ.

\section{- Cleaning and grading machine construction:}

The machine unit prototype under study was developed. It was manufactured with locally available materials in a local workshop.

\section{- The components of the constructed cleaning and grading machine} (Fig.1):

The machine prototype consists of the following main parts machine frame, power source and power transmission system, Functional units. This consists of:
a. Feeding system.
b. Sieving mechanism
c. Conveying mechanism

a. Machine frame: The main parts of the machine frame were made of a hollow rectangular and square steel iron section.

b. Power Source: The power source utilized in this machine is an electrical motor of $(3 \mathrm{~kW}) ; 50(\mathrm{HZ}) ; 220 \mathrm{~V}$ at rotating speed of $1460 \mathrm{rpm}$, single phase.

\section{Functional units:}

c. Feeding unit: The feeding unit consists of a hopper with a metering device for controlling the rate of feeding.

- Sieving unit mechanism: The sieving unit mechanism consists of the following parts:

The shoe is the vibrating or shaking section. It is mounted freely to the machine frame by four shock absorbers which provide the necessary flexibility required for the oscillation. Good seed are drooped through screen perforations but larger materials are carried over the screen into a separate spout. While the lower screen for grading in which good seed 
ride over the screen openings, while smaller particles drop through and discharge from the lower spout.

\section{Instruments:}

\section{Terminal velocity apparatus:}

The apparatus used in this study is shown in the Fig. (2). It consists of an electric blower which discharges air into a transparent tapered tube fixed at outlet side of blower through and below. A screen is fitted at a bottom of the tube of $8 \times 4 \mathrm{~cm}$ cross section. A check valve is built as the bottom of the cyclone to control the air flow rate.

\section{Anemometer:}

TRI-SENSE, Hygrometer, Anemometer, thermometer, model no. 3700000 code-Parmer Instrument, Vernon Hills, USA made was used for measuring the air velocity.

\section{Electronic digital venire caliper:}

Used for measuring the dimensions of grain and their associated foreign matters.

\section{Electric digital balances:}

The electric balance was used in this study to measure the mass of samples.

\section{Stop watch:}

Used for measure the time in seconds during tests.

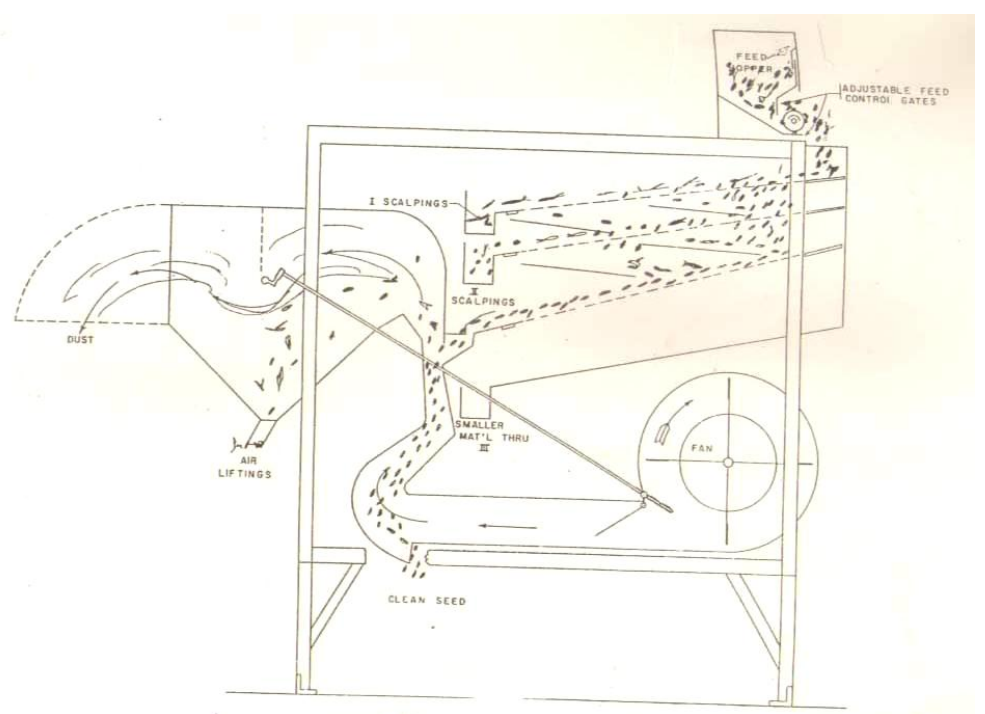

Fig. (1) Flow diagram of air-screen cleaner. 


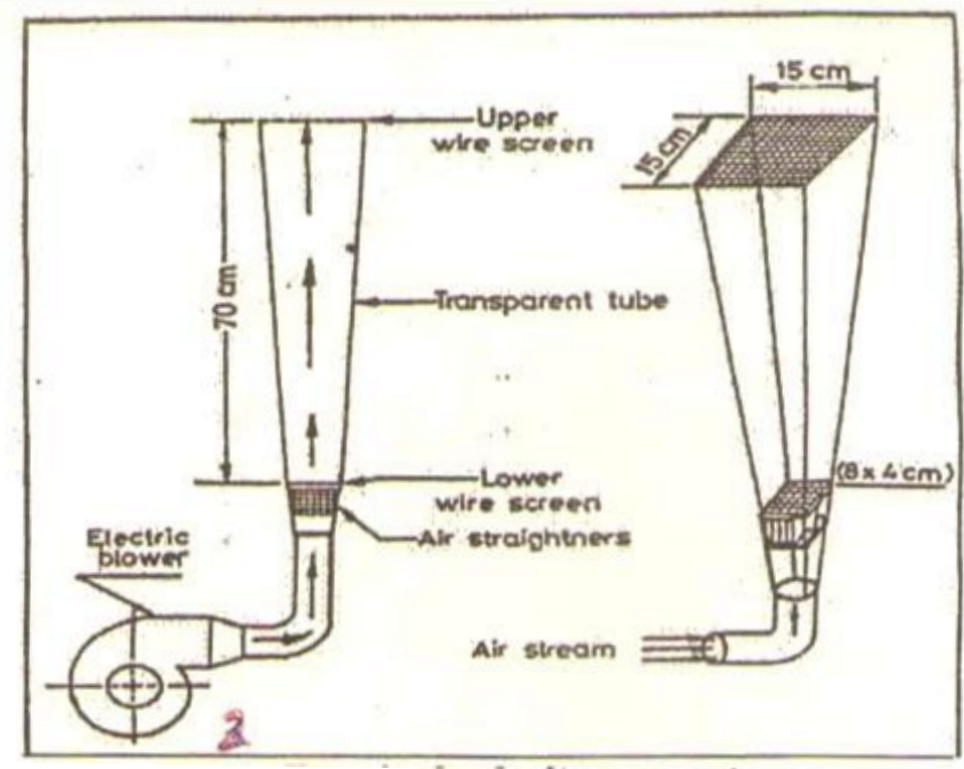

Fig. (2) Terminal velocity apparatus.

\section{Methods:}

Physical and mechanical properties of seed:

The properties of seed have to be considered for designing or developing a local seed cleaning and grading machine, or planter. Some properties were studied for broad beans (Giza 461). The studied properties of the seed were: seed size (dimensions) length, width, real and bulk density, projected area, terminal velocity, drag coefficient, Reynolds numbers. Sample of about 500 grains was taken randomly from seed lots in order to determine the mentioned properties at air dry storage moisture content of (14$18 \%)$.

\section{Air terminal velocity:}

The determination of air terminal velocity and drage coefficient characteristics is needed to estimate the behavior of seed and other materials in air stream to establish blower design. The terminal is velocity required to suspend a particle in a vertical air stream in the test apparatus fig. (3) Shows the relation ship between terminal velocity and mass of seed it was a linear.

Fig (4) also shows the terminal velocity also streat with the mass.

Fig (5) shows an inverse relationship for mass and drag Co. Also Fig (6) and (7) shows the drag coeff. and Re. 


\section{Machine tests:}

\section{Feeding rate adjustment:}

The first preliminary tests were carried out to select the suitable opening of the feed hopper gate. Three distances of the hopper gate openings, measured from the hopper side marked were $1.5,2$ and $3 \mathrm{~cm}$. tests were repeated four tines at each opening (replicated) $10 \mathrm{~kg}$ of harvested crops was used in each test. Duration time spent in feeding this amount to screening units was recorded. Results showed that the feed rate increased by increasing the hopper gate opening.

\section{Air flow adjustment and evaluation:}

The second series of the preliminary investigation were carried out to find out suitable of air velocity at discharge opening the fan duct for every crop variety and their associated foreign materials. The work started with the lowest fan speed and was gradually increased to the extent of started of blowing good kernels out of the machine unit. The control of air velocity was also achieved by adjusting the opening of the air intake in the two sides of fan housing.

Four different controls of air flow opening gates diameter were $5 ; 10 ; 15$ and $20 \mathrm{~cm}$. Tests were replicated four times at each openings with every fan speed of $215 ; 285 ; 350$ and $420 \mathrm{rpm}$.

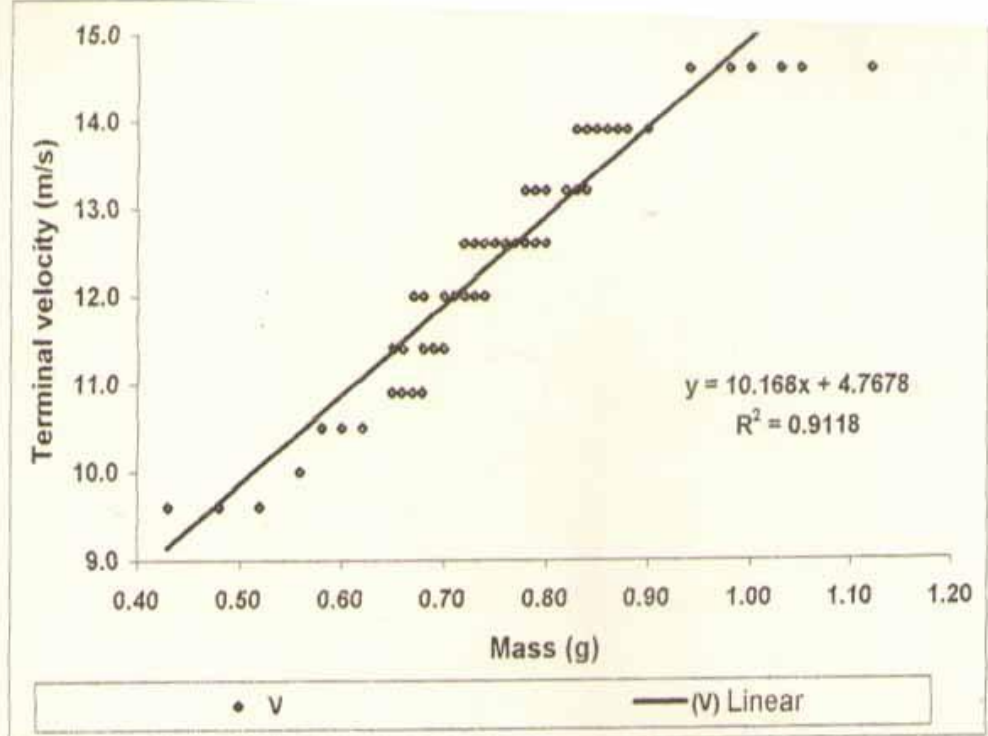

Fig. (3) Terminal velocity, Vs. Mass for broad beans (Giza 461). 


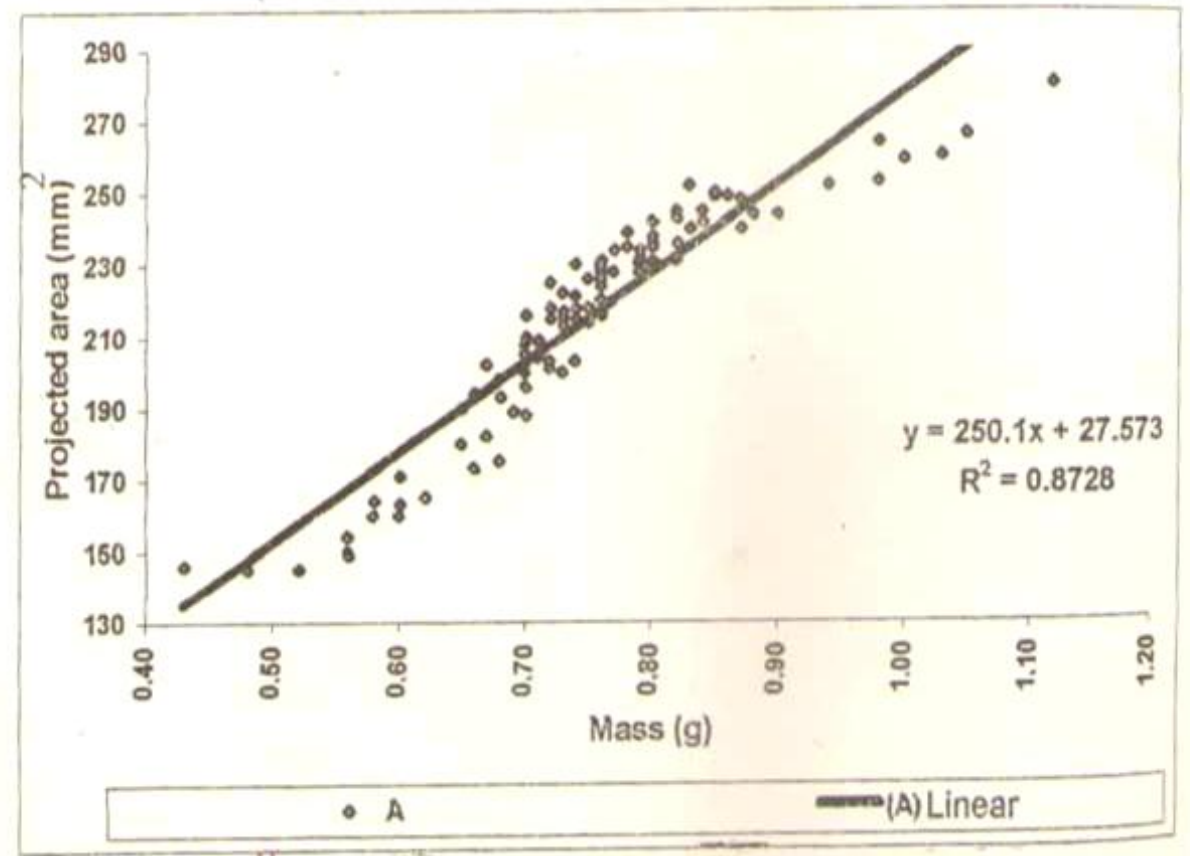

Fig. (4) Mass Vs. projected area for broad beans (Giza 461).

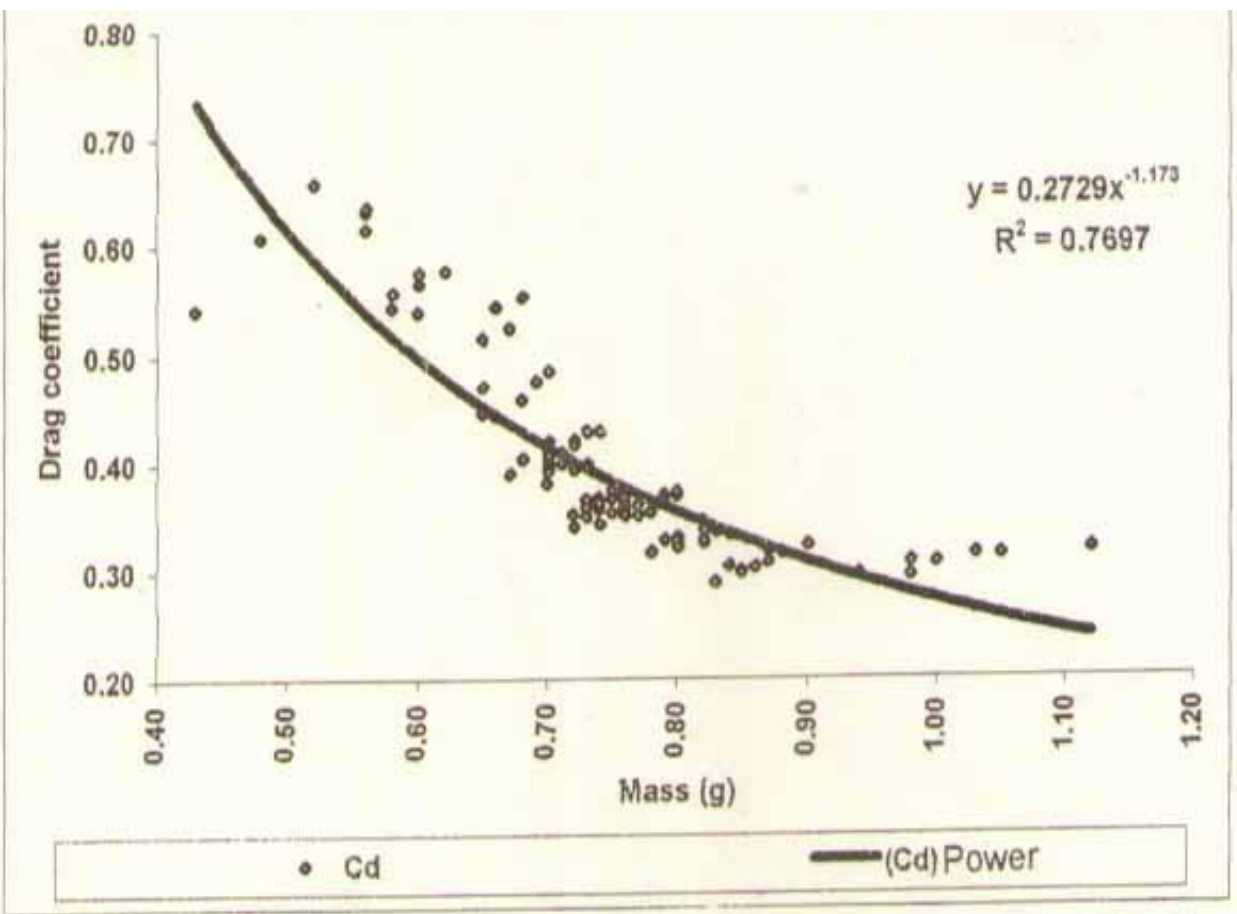

Fig. (5) Drag coefficient Vs. projected area for broad beans (Giza 461). 


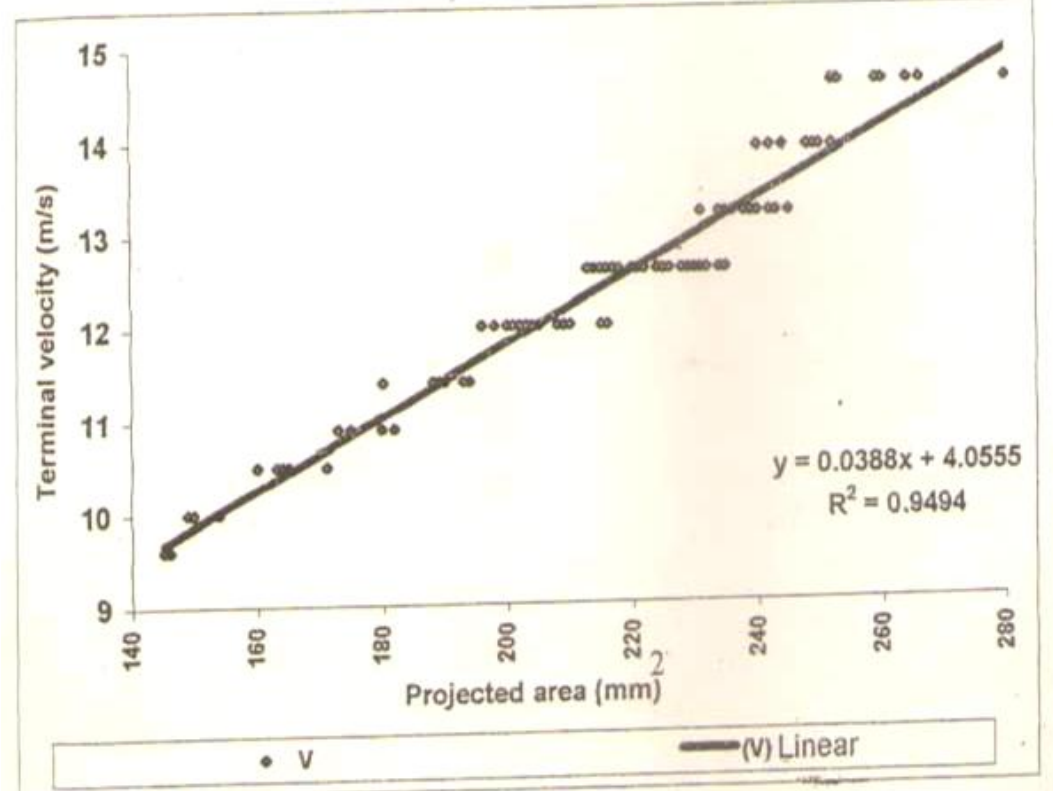

Fig. (6) Terminal velocity. Vs. projected area for broad beans (Giza 461).

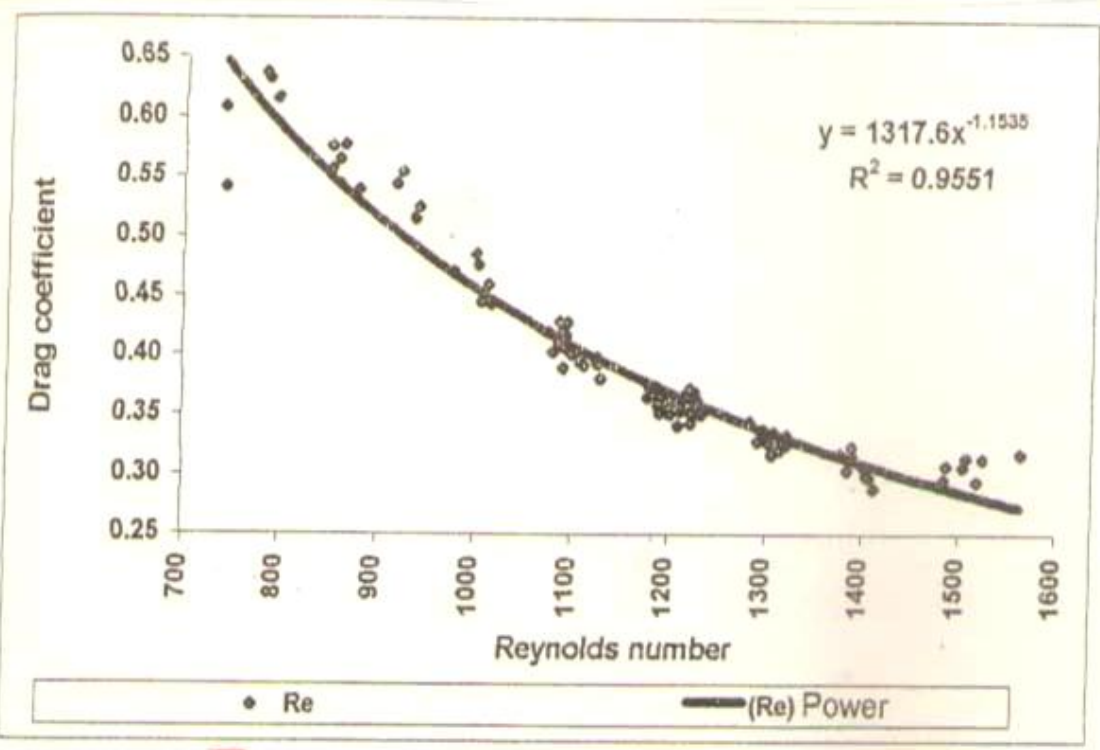

Fig. (7) Drag coefficient VS. Reynolds number for broad beans (Giza 461). 


\section{Cleaning, grading and conveying processes:}

Small hand testing screens were used to test samples for determining the best screen opening size arrangement before setting-up production size units. This can be done with small sample of the seed. The feed hopper receives the lots of seed to be cleaned and grading, and feeds it at a controlled rate to the cleaning components of the unit. Rate of feed is controlled by a sliding gate at the bottom of the hopper.

The seed or grain is eyeleted through the hopper gate in a uniform layer across the full width of the top screen. Good shoe by gravitational force. The streams of cleaned and graded seed on the bottom screen are joined, routed and falls in the vertical air column of the bottom blast fan for a final accurate air separation by weight. The top screen removed large pieces of cob, stem, stones, leaves and over - sized kernels.

The bottom screen removed under - sized kernels, broken kernels, small foreign material and weed seed. The vertical air removed small pieces of cob, stem, leaves, husk, thin, light-weight kernels, dust and chaff. A conveying unit system is designed to convey the screenings commodity from discharge tank to out side of the machine for bagging.

\section{Test procedures on the experimental aeromechanical cleaning and grading machine:}

Test variables: the following factors were tested to show their effect on the modified machine performance as follow:

Feed rate: three different feed rates were under test 250,500 and 750 $\mathrm{kg} / \mathrm{h}$. Small graduate cylinder when the seed sample was dropped and immersed in the solution.

Seed bulk density: This property was calculated for the grains of the investigated crops varieties, by dividing the mass of a quantity of grains of each variety by its bulk volume which was measured by using graduate cylinder as follows:

Where:

$$
\mathrm{D}_{\mathrm{b}}=\mathrm{W} / \mathrm{V} \quad \mathrm{g} / \mathrm{cm}^{3}
$$

$D_{b} \quad:$ is the bulk density of grains, $\mathrm{g} / \mathrm{cm}^{3}$.

$\mathrm{W} \quad$ : mass of grains, $\mathrm{g}$

$\mathrm{V} \quad$ : bulk volume of the sample, $\mathrm{cm}^{3}$. 
The considered values are the average of four recorded replicates.

\section{Air terminal velocity:}

The determination of air terminal velocity and drag coefficient characteristics was needed to estimated the behavior of seed and other materials in air stream with a degree of certainty and so a definite basis to establish blower design the terminal velocity of agricultural products is determined by measuring the air velocity required to suspend a particle in a vertical air stream, in the test apparatus. Terminal velocity of the investigated crops were measured where the net at the inlet side of the transparent tube. After operating the blower, increasing the blower speed by closing the gate slowly and gradually until the air stream suspend the particle in the vertical active part of the transparent tube. The measured air velocity in this case represents the terminal velocity of the particle. The velocity readings were taken by the anemometer at the tube center when the material under test was floating in the air stream.

\section{Seed drag coefficient:}

The drag coefficient $\left(\mathrm{C}_{\mathrm{d}}\right)$ of the seed was calculated according to the following equation (hexing 1989).

$$
F_{d}=1 / 2\left(C_{d}, A_{p} \cdot P_{a} \cdot V^{2}\right)=M g
$$

Where:

$\mathrm{F}_{\mathrm{d}} \quad$ : the drag force; $\quad$ M: mass $\quad$ g: gravity

$\mathrm{A}_{\mathrm{p}} \quad$ : frontal area of particle; $\quad \mathrm{P}_{\mathrm{a}}$ : density of air;

$\mathrm{V} \quad$ : relative air velocity; $\quad \mathrm{C}_{\mathrm{d}}$ drag coefficient

\section{Reynolds number:}

The Reynolds number characterizing the nature of the flow (laminar, turbulent and transitional) must be known.

Reynolds number $\left(\mathrm{N}_{\mathrm{Re}}\right)$ was calculated from the following equation.

$$
\mathrm{N}_{\mathrm{Re}=} \frac{P_{a} V_{1} \sqrt{A_{p}}}{\mu}
$$

Where:

$\mathrm{N}_{\mathrm{Re}} \quad$ : Reynolds number, dimensionless.

$\mathrm{P}_{\mathrm{a}} \quad$ : Air density, $1.28 \mathrm{~kg} / \mathrm{m}^{3}$.

$\mathrm{V}_{\mathrm{t}} \quad$ : Terminal velocity of the particle, $\mathrm{m} / \mathrm{s}$.

$A_{p} \quad$ : Project area of the particle perpendicular to air stream, $\mathrm{m}^{2}$. 
$\mu \quad$ : Dynamic viscosity of the air, $18: 10^{-6}$ pa.s

Laminar flow $\mathrm{N}_{\mathrm{Re}}<2100$, turbulent flow $\mathrm{N}_{\mathrm{Re}}>4000$,

Transition flow $2000>\mathrm{N}_{\mathrm{Re}}<4000$

The Reynolds number is

$\mathrm{N}_{\mathrm{Re}}=\mathrm{V}_{\mathrm{t}}$ d $\quad$ P. a I $\mu$

Where: $\mathrm{N}_{\mathrm{Re}} \quad$ : Reynolds number, dimensionless

$\mathrm{V}_{\mathrm{t}} \quad$ : Terminal velocity of the particle, $\mathrm{m} / \mathrm{s}$.

$\mathrm{D} \quad$ : the typical length of the air duct, $\mathrm{m}$

$\mathrm{P}_{\mathrm{a}} \quad$ : the density of the air, $1.28 \mathrm{~kg} / \mathrm{m}^{3}$.

$\mu \quad$ : dynamic viscosity of the air. $18.10^{-6} \mathrm{~Pa} . \mathrm{s}$

\section{Machine unit measurements:}

\section{The speeds of rotating shafts:}

This speed of rotating shafts was measured by means of hand contact Tachometer which gives he speed in rpm. The speed of rotation for conveyor drive shaft, screen crank drive shaft, brush drive shaft, fan drive shafts were recorded.

\section{Air flow rate:}

The air flow rate through the fan outlet ducts was measured at specified points by means of an Anemometer. The measurements were taken through the rectangular cross section area of the fan outlet duct at a point away $1.0 \mathrm{~m}$ from the fan outlet. This rectangular cross sectional area was divided into

\section{Experimental procedures for modified machine:}

The main experiments were conducted to evaluate the engineering and operational machine parameters affecting the cleaning, grading and conveying processes of the studied grains. All experiment were carried out at different combinations of sieving unit different feed rates in the cleaning, grading (separation) and conveying processes.

\section{Parameters of cleaning and grading evaluation:}

A predetermined mass of a mixture consisted of grain and chopped straw was fed to the machine though the hopper the feed rate was controlled by using a sliding gate located at the bottom of the hopper. The recovered grain in product and the chopped straw in reject were collected and mass/chopped straw associated with grains was separated manually and massed. The rejected material which consists mainly of chopped materials 
and small amount of grains were separated and determined. The effectiveness of separation was calculated according to Kashayap's and Panda equation (1965), as following:

\section{A. The effectiveness of separation}

$$
\mathrm{y}=\left[\left(\mathrm{m}_{\mathrm{gp}} \mathrm{m}_{\mathrm{er}}-\mathrm{m}_{\mathrm{cp}} \mathrm{m}_{\mathrm{gr}}\right) /\left(\mathrm{m}_{\mathrm{gp}}+\mathrm{m}_{\mathrm{gr}}\right)\left(\mathrm{m}_{\mathrm{cp}}+\mathrm{m}_{\mathrm{er}}\right)\right]
$$

where:

$\mathrm{m}_{\mathrm{gp}}: \mathrm{m}_{\mathrm{cp}}, \mathrm{m}_{\mathrm{gr}}, \mathrm{m}_{\mathrm{er}}$

[ $\left(\mathrm{m}_{\mathrm{gp}}\left(\mathrm{m}_{\mathrm{gp}}+\mathrm{m}_{\mathrm{gr}}\right)\right.$ : the proportion of the grain recovery

[ $\left(\mathrm{m}_{\mathrm{er} /}\left(\mathrm{m}_{\mathrm{er}}+\mathrm{m}_{\mathrm{ep}}\right)\right.$ : the proportion of the chaff reject according to the above mentioned formula, the percent of grain recovery in product was calculated as follows.

\section{B. Grain Recovery}

Grain Recovery \% $=\left[\left(\mathrm{m}_{\mathrm{gp}}+\mathrm{m}_{\mathrm{gr}}\right)\right]$ :

\section{C. the degree of cleanliness:}

The degree of cleanliness of grain recovery in product was also calculated as follows:

2. Machine grading capacity and efficiency

The grading capacity and efficiency for the developed handling machine were determined according to Amin 1994 as:

$$
\mathrm{W}=\mathrm{m} 1 \times \frac{60}{1}
$$

\section{Estimation of power and energy requirements:}

The consumed power $(\mathrm{kW})$ was estimated by measuring the line current strength (1) in amperes and potential difference (V) in volts and using the following formula.

Total consumed power $=\mathrm{I} \cdot \mathrm{V} \cdot \cos \quad / 1000 \mathrm{~kW}$;

\section{RESULTS AND DISCUSSION}

The average properties of: Broad Beans: (Giza 461)

Some of the physical aerodynamic

M Mass of 1000 - Kernels, (g) 757

Av. Dim Average dimensions, $\mathrm{mm}$

L Length, mm, 14.76

W Width, mm, 10.85

$\mathrm{T}$ Thickness, mm 5.92

$\mathrm{P}_{\mathrm{r}} \quad$ Specific density, true $\mathrm{g} / \mathrm{cm}^{3} 1.285$ 
$\mathrm{P}_{\mathrm{b}} \quad$ Bulk density, $\mathrm{g} / \mathrm{cm}^{3} 0.672$

Ap Projected area, $\mathrm{cm}^{2}, 2.15$

Vt erminal velocity, $\mathrm{m} / \mathrm{s}$ Av. 12.41

Cd Drag coefficient, dimensionless 0.396

Re Reynolds number, dimensionless 1170.92

$\partial \quad$ External friction angle, degree $\quad 25.5$

$\theta \quad$ Angle of repose, degree, 28

Ghard Grain hardness, N. $\quad 3.55$

S Percent of sphericity Av. 0.66

$0.52-0.91$

M.C (d,b\% 14-18\%).

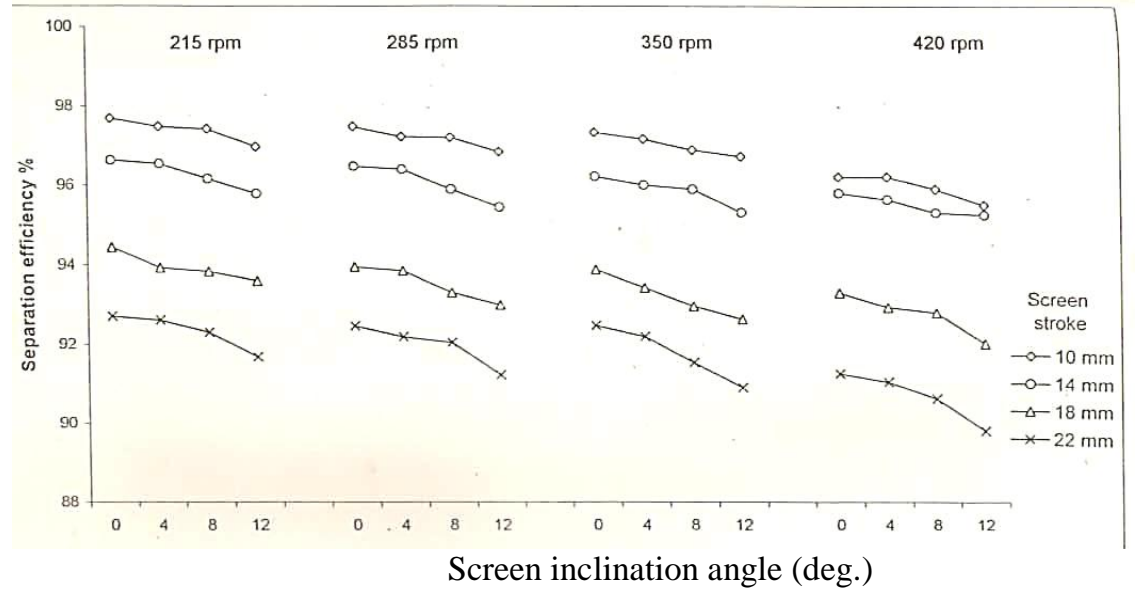

Fig. (8) Effect of different screen oscillation: screen inclination and screen amplitude on separation efficiency at feed rate $500 \mathrm{~kg} / \mathrm{h}$ for broad beans

(Giza 461).

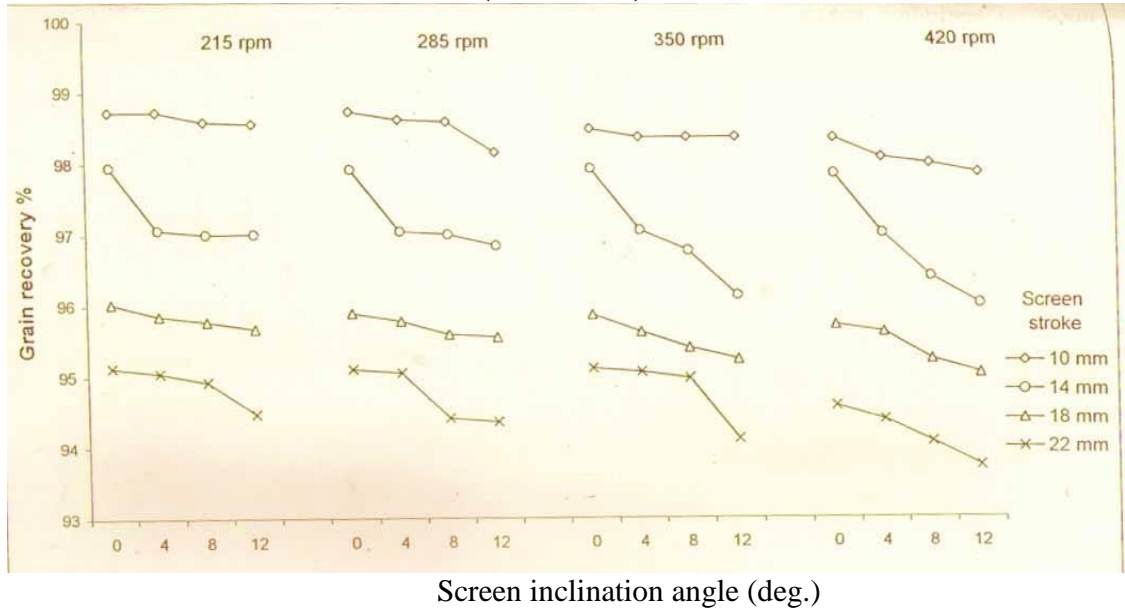

Fig. (9) Effect of different screen oscillation: screen inclination and screen amplitude on grain recovery at feed rate $500 \mathrm{~kg} / \mathrm{h}$ for broad beans (Giza 461). 


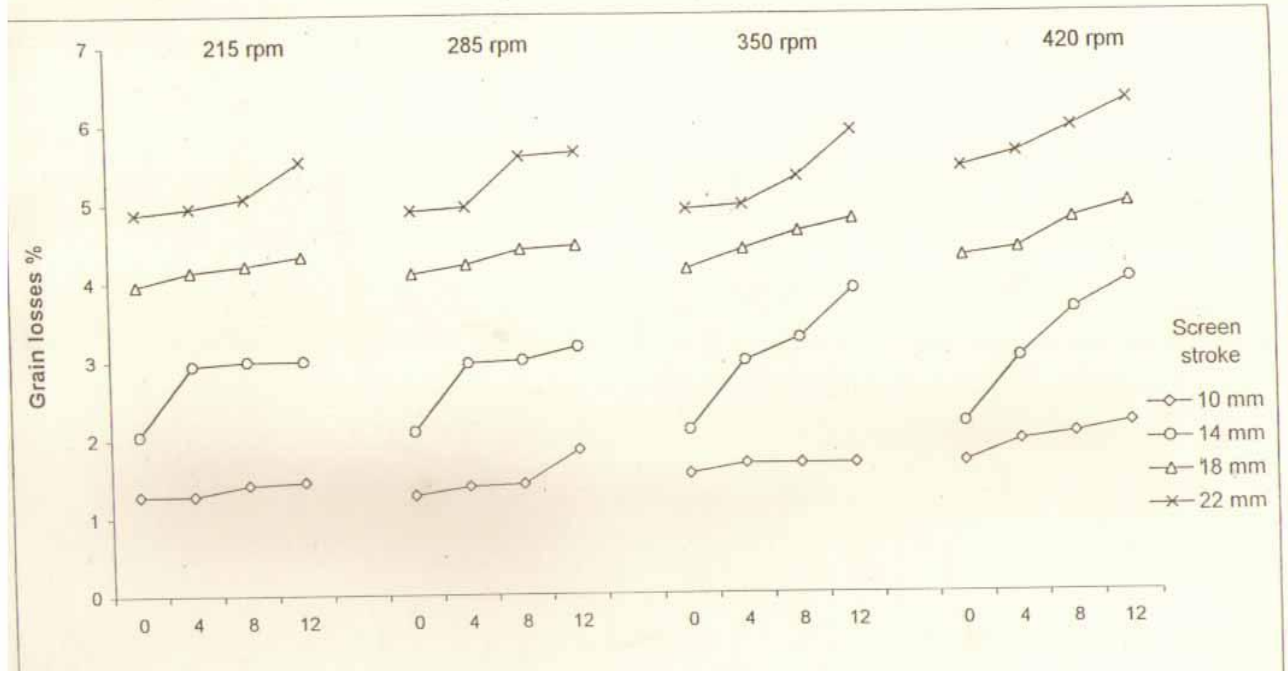

Screen inclination angle (deg.)

Fig. (10) Effect of different screen oscillation: screen inclination and screen amplitude on grain losses at feed rate $500 \mathrm{~kg} / \mathrm{h}$ for broad beans (Giza 461).

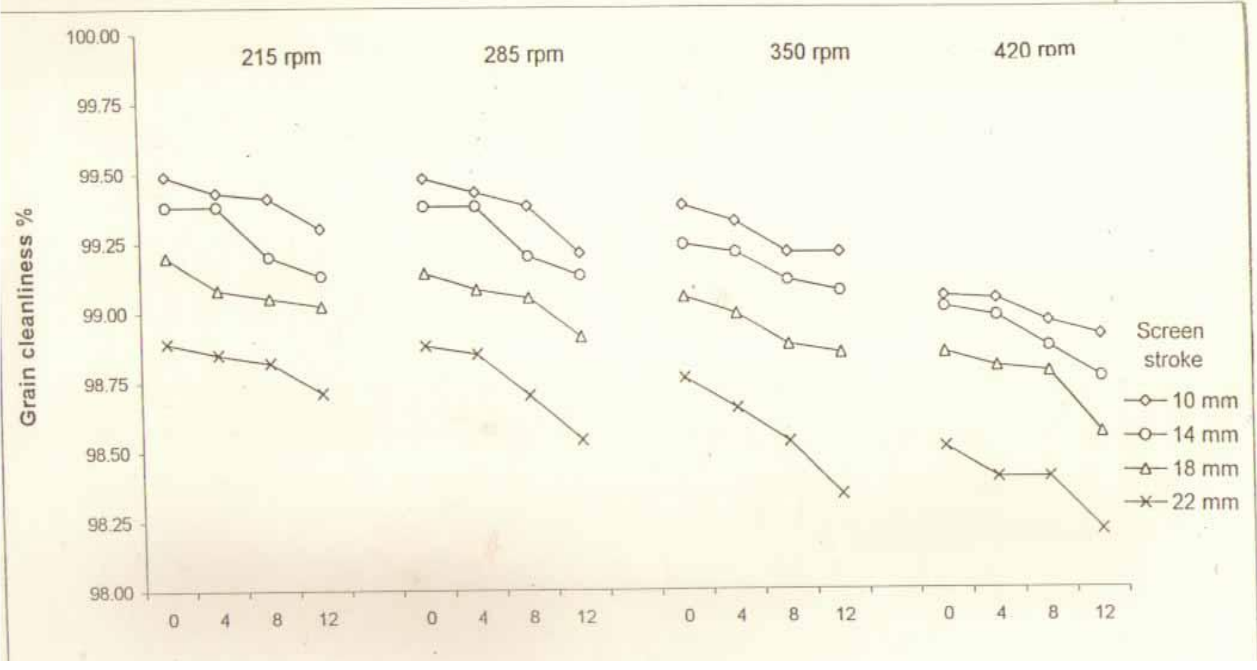

Screen inclination angle (deg.)

Fig. (11) Effect of different screen oscillation: screen inclination and screen amplitude on grain cleanliness at feed rate $750 \mathrm{~kg} / \mathrm{h}$ for broad beans (Giza 461). 


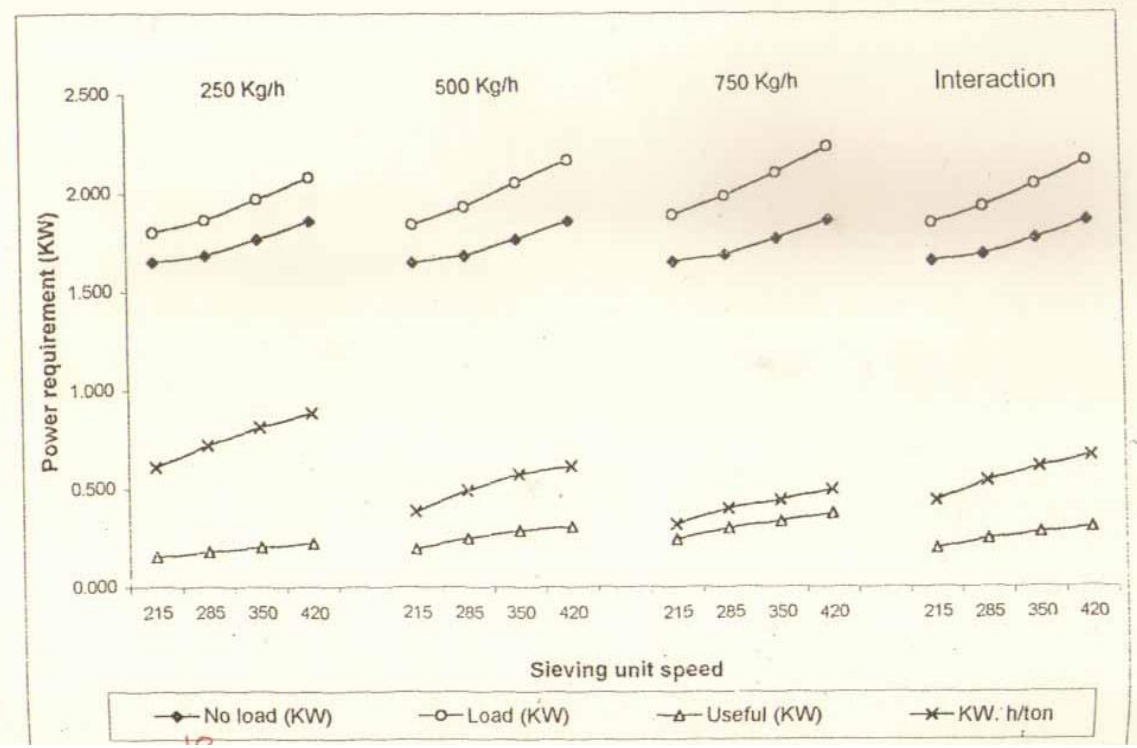

Fig. (12) Effect of feeding rate and sieving unit speed on the power and energy requirement for the seed lots during cleaning and grading process.

Considerations due to the results on studied physical and aerodynamic properties of seeds.

In this study, separation by any single characteristic will be impossible without great losses. Thus two characteristics were used to separate the investigated seed (width and terminal velocity) of every grains and their foreign materials were not and partially overlapping.

The constructed cleaning and grading is made on the basis of differences in seed dimensions (using mechanical screen) and seed weight) According to the results of study of the physical and engineering properties show that, the selected optimum terminal velocity $(10.9 \mathrm{~m} / \mathrm{s})$ and round hole diameter of the upper and lower screens due to crops seeds (13 and $9 \mathrm{~mm}$ ).

1. Separation efficiency \%: Fig (8)

The highest percentage values was $98.45 \%$, at screen oscillation 215 $\mathrm{rpm}$, inclination zero deg, amplitude $10 \mathrm{~mm}$ and Feed rate $250 \mathrm{~kg} / \mathrm{h}$. and $500 \mathrm{~kg} / \mathrm{h}$.

2. Grain recovery \%: Fig (9)

The highest percentage value was $99.30 \%$ at screen oscillation $215 \mathrm{rpm}$, inclination zero amplitude $10 \mathrm{~mm}$ and feed rate $250 \mathrm{~kg} / \mathrm{h}$. 


\section{Grain Losses \%: Fig (10)}

The lowest percentage value was $0.70 \%$ at screen oscillation $215 \mathrm{rpm}$, inclination zero deg, amplitude $10 \mathrm{~mm}$ and feed rate $250 \mathrm{~kg} / \mathrm{h}$.

\section{Grain Cleanliness \%: Fig (11)}

The highest percentage values was $99.66 \%$ at screen oscillation $215 \mathrm{rpm}$, inclination zero, amplitude $10 \mathrm{~mm}$ and feed rate $250 \mathrm{~kg} / \mathrm{h}$

5. Power requirement: For modified machine unit: Fig (12)

The results indicated that the power required to operate the modified machine, increased as feeding rate and sieving unit speed increased. The maximum value of power requirement for cleaning and grading processing was found to be $2.229 \mathrm{~kW}$ at sieving unit speed of $420 \mathrm{rpm}$ and feeding rate of $750 \mathrm{~kg} / \mathrm{h}$.

From experiments the impurities, empty, shrink, weed, seeds small cobs stem, dust and stones were almost completely removed with an air flow velocity of $10.85 ; \mathrm{m} / \mathrm{sec}$.

\section{SUMMARY AND CONCLUSION}

Separation is based on differences in the physical properties between the desirable seed and undesirable adulterants. It must be studied to determine the most effective method and equipment to give the most efficient separation. Specific gravity (weight) properties are common among seeds and between the particles of adulterants and seed, and therefore are the most common used in the separation process. Consequently, the cleaning and grading equipment which utilized dimensional (size) and specific gravity (weight) differences is primary in seed and grain cleaning and grading process.

The present study aims to modify and develop a small, simple, and cheep machine for cleaning and grading Egyptian crop seeds, by using both mechanical and aerodynamic methods, suitable for the small village. The developed machine was constructed locally from available material which purchased from domestic market and fabricated to ensure low initial cost and availability of spare parts and ease cleaning and repair. The parameters involved in grading machine and analysis the behavior of 
particles and forces acting during grading process, to achieve the optimum conditions for cleaning, grading and conveying operations. To evaluate the performance of the modified cleaning and grading machine, a series of experiments were carried out to study some parameters, such as the effect of screen oscillation speed inclination, Broad beans (Giza 461); grading operations. The main results obtained from the experiments were summarized in the following main points:

Te average mas of 1000 kernels 7579, Length $14.7 \mathrm{~mm}$, width $11 \mathrm{~mm}$, thickness $6 \mathrm{~mm}$, specific density $1.28 \mathrm{~g} / \mathrm{cm} 3$, projected area $2.15 \mathrm{~cm} 2$, terminal velocity 12.4 drag coefficient 0.396 , Reynolds number 1170 , and spherically 0.66 at M.C $14-18 \%$. Separation efficiency was $98 \%$ at screen oscillation $2 / 5 \mathrm{rpm}$, Zero deg. feed rate $250 \mathrm{~kg} / \mathrm{h}$. Grain recovery was $99 \%$, grain loss was $0.70 \%$, grain clean lines was $98 \%$ at the same conditions.

\section{REFERENCES}

Awady M.N and A.S. El-Sayed (1994). Separation of peanut seeds by air stream. Misr. J.Ag. Eng. 11 (1): 137-147.

Dosoky, S.H. (2011). Physical, Mechanical and aerodynamic properties of sayabans for separation and grading machines, Annual Journal of Ag. Eng, 647 -662.

El Fawal. Y.A. (2004). Engineering and operational considerations in developing a seed grading unit. $\mathrm{PhD}$. Th. Azhar Univ.

Kaairy, M.F and A. Nakib (1989). The effect of vertical and horizontal air streams on sun flower kernel separation, Misr. J.Ag. Eng. (612): $186-200$.

Nakib A.A. (2000). Development of a seed grading unit to improve the efficiency of seed planters. Agr. Eng. Dept. Al -Azhar Unvi.

Sitkei, G. (2014). Mechanics of agricultural materials developments. Agricultural Egn. Handbook, N. Y: 294-295. 


\section{الملخص العربي \\ تطوير ماكينة لتنظيف ولتدريج الفول البلاي}

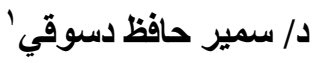

يعتبر محصول الفول البلدي من المحصيل البقولية الاستر اتيجية في الغذاء الثعبي وتقدر المساحة

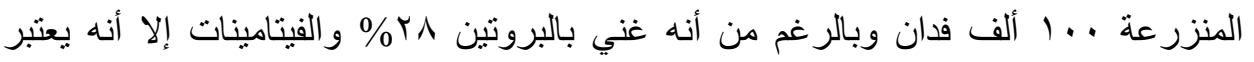
مصدر جيد لزيادة المحتوى الأزوتي للتربة.

وتعتبر عملية تنظيف وتدريج الحبوب من أهم العمليات التي تجري على المحصول. ومن هنا برزت الحاجة لنظوير آلة لتنظيف وتدريج الحبوب.

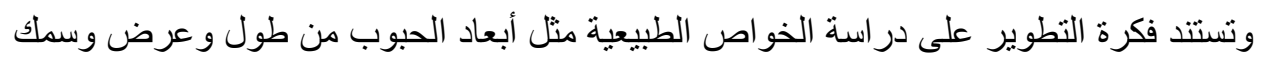

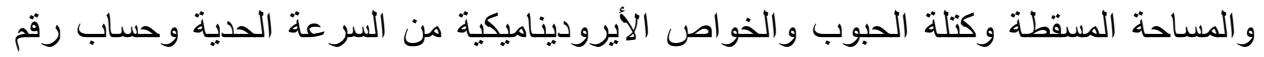

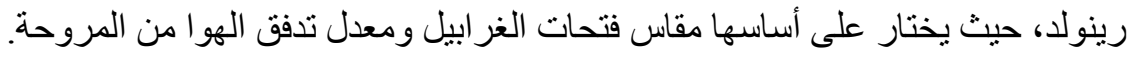

وبناءًا عليه تم دراسة معدلات التغذية وميل الغرابيل وأختيار السرعة وتقدر الطاقة المستهلكة

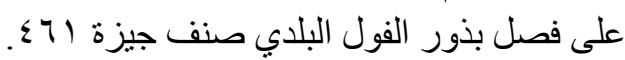

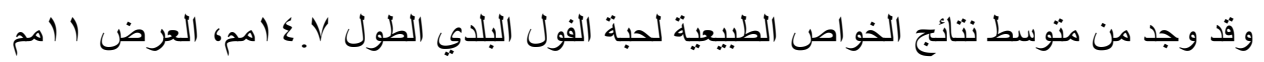

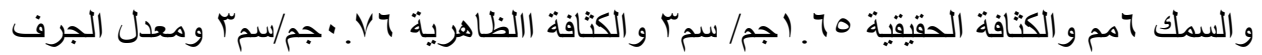

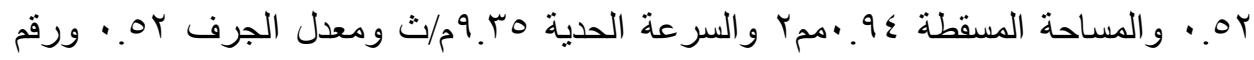

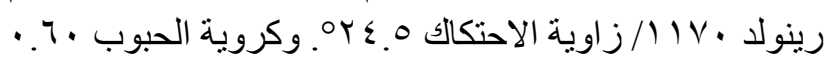

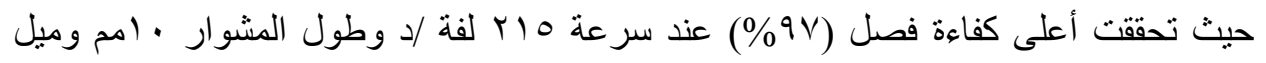

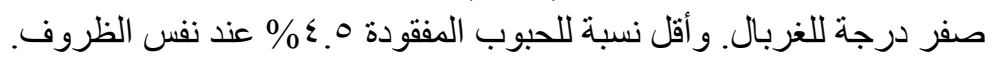

$$
\text { وكانت السر عة المثلى لطرد الهو اء للشو ائب الم/ث. }
$$

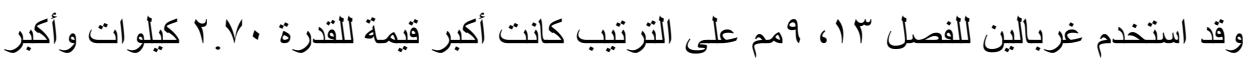

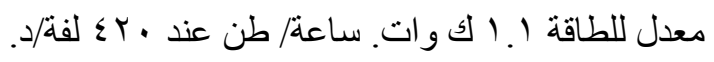

' أستاذ مساعد كلية الهندسة الزراعية - جامعة الأزهر. 